\title{
FORMS AND LEVELS OF RATIONALITY IN HOBBES*
}

\author{
Ermanno VITALE
}

\section{Resumen:}

Después de un rápido recorrido sobre las múltiples interpretaciones del pensamiento hobbesiano, el ensayo retoma y desarrolla la lectura que de Hobbes propuso Norberto Bobbio. Con base en esta lectura, se busca evaluar el legado metodológico de Hobbes, el cual se despliega a través de distintos niveles de racionalidad: en primer lugar, el razonamiento basado en dicotomías, el cual desafió de manera contundente la tradición aristotélica, la labor de los historiadores antiguos y la hermenéutica bíblica de los teólogos medievales. En segundo lugar, el individualismo como método para tomar decisiones colectivas, lo que abrió la puerta a la así llamada "teoría de juegos" y al individualismo moral tan notable en la filosofia política contemporánea. Y finalmente, la racionalidad del poder político, que lógicamente impone sobre la soberanía ciertas reglas vinculantes para obtener y mantener el poder.

En conjunto, con el análisis de las distintas formas y niveles de racionalidad se pretende respaldar la idea de que Hobbes —antes de ser identificado como un defensor de regímenes autocráticos- puede ser considerado como un autor clave para la democracia y el constitucionalismo moderno, colocado en el justo inicio de la larga historia del Estado de derecho.

\section{Palabras clave:}

Thomas Hobbes, filosofia politica, racionalidad, individualismo, metodologia.

\footnotetext{
* Translated into English by Patricia Mindus.
} 


\title{
ERMANNO VITALE
}

\begin{abstract}
:
The article aims to assess Hobbes' methodological legacy. After a brief review of different interpretations of Hobbes relevant to the subject, I center the discussion on the reading advanced by Norberto Bobbio and the notion of three "different forms and levels of rationality": First, Hobbes' dichotomy-based reasoning that radically contended the Aristotelian tradition, as well as biblical hermeneutics used by medieval theologians. Second, individualism as a method for collective decision making, one that led to so-called "game theory" and moral individualism (quite significant in contemporary political philosophy). Finally, the rationality of political power that imposes on Sovereignty binding rules for gaining and maintaining power.

After the discussion of the three different forms and levels of rationality, the article concludes that Thomas Hobbes, instead of being primarily referred to as an advocate of autocratic regimes, should be considered, at the very beginning of the long history of rule of law, as one of the key authors of modern constitutionalism and democracy.
\end{abstract}

\section{Keywords:}

Thomas Hobbes, Political Philosophy, Rationality, Individualism, Methodology. 
FORMS AND LEVELS OF RATIONALITY IN HOBBES

Summary: I. Hobbes: A Man of Utter Reason. II. The Lesson in Method: Hobbes' Model and the Great Dichotomies. III. Individualism(s). IV. The Rational Bond. Laws of Winning and Laws of Gaming.

\section{Hobbes: A Man of UtTer ReAson}

All great philosophers of the past, and primarily political thinkers have in time been the object of diverse and sometimes contrasting readings. This is also true in the case of Hobbes of course. After a few centuries of ostracism, when it was inopportune and often dangerous to quote him, if it were not to condemn him without appeal, bookshelves have now been filled. For the sake of convention, modern Hobbes studies started with Ferdinand Tönnies' voluminous monograph from 1896. From that moment on, the great variety of Hobbes readings seems to have been physiological to a certain extent, and pathological to some degree. The plurality of interpretations that are well-documented and firmly grounded in Hobbes' corpus philosophicus (or at least in his political writings) is physiological. However, pathological are those readings that partially disregard or overturn the letter of the texts, thus avoiding to check the solidity of the interpretation against the overall architecture of the Hobbesian system of political philosophy. It is certainly warranted to extrapolate specific aspects of Hobbes' doctrine in order to build new theories or to draw on a particular suggestion or reasoning. In my opinion, caution should nevertheless apply, when such legitimate, and perhaps useful, "intellectual loans" are being confused with plausible, general interpretations of the author from which the credit has been taken; in this case, Hobbes.

A few examples illustrate this well: The readings of Strauss (1936), Schmitt (1938), Warrender (1957) and Watkins (1965) are all divergent, if not incompatible, and yet they are all reasonable, in the sense that each one is textually well-grounded and attempts to give a coherent 
and systematic view of the crucial aspects of Hobbes' thought. In the Italian tradition, the same might be said of the Hobbes readings of Norberto Bobbio (1989), Tito Magri (1982) and Mario Reale (1991), to name but a few.

However, the same cannot be said about some other (Anglo-Saxon) readings that have strong influence over recent Hobbes studies. In particular, the reference goes to the work of Gauthier (1969), Kavka (1986) and Hampton (1986) who read Hobbes in conjunction with the sophisticated and formal language of game theory and rational choice theory. These readings bring on the impression that unwarranted updating and forceful interpretations have become inevitable. The prisoner's dilemma is not the only attempt to twist Hobbes' pen. Just as unlikely readings have been suggested from rather distant philosophical traditions, such as the existentialist and Heideggerian interpretation of Yves Zarka (1987).

A blatant aspect in Hobbes' work is his outspoken intention to apply the rational method to the study of politics; based on reason as the faculty of calculating, adding and subduing definitions. This is the reason why he holds himself to be the true founder of civil philosophy, the pioneer who laid the foundation of this field of study, like Euclid did in geometry and Galileo in physics. Just as evident and complementary is Hobbes' blunt aversion for the ignes fatui of rhetoric that he opposed to the "dry discourse" of mathematical and geometrical sciences.

When confronted with what we might call "pathological", i.e., biased or flawed readings, these passages need to be bore in mind. This methodological advise helps us not only to discard eccentric interpretations, but also to avoid overloading Hobbes with disproportionate and improper claims, such as those put forth by the so-called neo-Hobbesians. So far, the brocade in claris non fit interpretatio is suitable.

From this point on, nevertheless, two different issues immediately emerge. First, we need to establish whether the shape that Hobbes gave Reason is still an interesting, 
methodologically convincing, and viable argumentative procedure. Secondly, we have to address another issue (in partial consequence of the first point): Is it still meaningful -and in what sense- to refer to the civil philosophy of the De Cive in contemporary political rationalism, in new forms of contract theory and Enlightenment-inspired positions? It is known, for instance, that the contract theory of John Rawls shuns the reference to Hobbes, in favour of Locke, Rousseau and Kant.

In order to avoid the two conflicting dead-end interpretations, modernizing Hobbes into game theory or rational choice theories, and transforming the king of reason into the prince of darkness, we should briefly outline the historical motives and theoretical arguments for promoting a reading of Hobbes as the "prince of Reason", following Norberto Bobbio's interpretation, who (re)introduced an understanding of Hobbes in Italy after the Second World War as father of modern contract theory and founder of political rationalism, finally freed from the allegation of being the forerunner of totalitarian regimes. Such a charge can be considered to be just another "pathological" reading based on the confusion between absolutism and totalitarianism (see e.g. Vialatoux 1935).

A perhaps redundant, yet needed clarification is that my aim is not to provide any detailed discussion of Bobbio's articulate and precise interpretation of Hobbes. Rather, the idea is to assess the methodological, and, in general, philosophical legacy of Hobbes for those who identify themselves in Enlightenment-inspired perspectives today. I use Bobbio as a paradigmatic reader of Hobbes, because I consider him to be the most consistent and alert exponent of the abovementioned position.

With a pun on the title of Giuseppe Sorgi's book on the history of Hobbes readings - Which Hobbes? - Bobbio asserted: "Which Hobbes? I would answer in a simple, or perhaps banal way: Hobbes, read with a minimum of common sense and historical awareness, which many critics lack, 
who search for novelties at any cost" (Bobbio 1996: 118). What are the requirements for such an interpretation that combines common sense and historical awareness? Bobbio summarized the reasons of the extraordinary influence Hobbes had on his own thought and, more generally, on modern and contemporary political thinking. An extensive quote is needed:

I admit that Hobbes is one of my authors. I have studied him periodically all my life. I do not recognize other [scientific] merits to myself than having realized the fundamental importance of Hobbes' political thought when he was still rather ignored, at least in Italy. But it is not hard to understand why: During the fascist era, his name was suspicious. It was not yet clear that the Leviathan is not the totalitarian State, but the modern state, the great territorial state, born out of the ashes of medieval society, a political body that historically took on different forms of government, among which autocracy is not necessarily included. The Leviathan is chiefly the holder of the monopoly on legitimate violence: Legitimate because it is founded on the consensus of the citizens (...). What stroke me the most was the innovativeness of Hobbes' method. The Hobbesian discourse was no longer grounded - as Grotius' famous book was to a great extentin the principle of historical or revealed authority, but it was based exclusively on rational arguments. It is correct to observe (...) that Hobbes' influence on my thinking depends more on method than content. However, I believe that, as far as content is concerned, some of Hobbes' ideas contributed to form my political thought. I indicate tree: Individualism, contract theory and peace through the institution of a common power (...). To this I would add a certain pessimism regarding history and human nature (Bobbio 1998: 117).

Here I shall critically examine, like Bobbio always invited us to do, at least two of these suggestions. First of all, I will look at the methodological legacy that, in my opinion, cannot be taken for granted; it might be less linear than if we understood it in the broad terms of a common perspective 
on analytic reason applied to law and politics. Consequently, individualism, as a conception of the world, will be taken into consideration. The different possible declinations of individualism become decisive for grounding, measuring, and assessing the various political formulas that can be harboured within the Leviathan, the essence of the modern state. From a normative perspective, the different forms of individualism are also important for describing and justifying the relations among the many Leviathans on the global arena. In other words, the different understandings of individualism are central when it comes to the fundamental political decision on war and peace.

\section{The Lesson in Method: Hobbes' Model AND THE GREAT DiCHOTOMIES}

In the aforementioned quote Bobbio singled out Hobbes' methodological influence primarily in his innovating substitution of the principle of authority with that of reason. However, this substitution does not imply any bland opposition between reason and faith, or any compromise in favour of reason which is ultimately defined in terms of divine light or moral sense. On the contrary, the idea suggests that we proceed in examining practical issues - moral, legal, political - through a rigorous form of demonstratio, grounded in clear definitions, instead of a dreary form of interpretatio that ruminates over tradition feeding on the auto-referential gathering of conceptual debris that have lost all their heuristic capacity.

According to Bobbio, Hobbes' methodological lesson does not seem to be chiefly geometrical reason, i.e., reason as a faculty of calculation that finally enables us to enact the civil philosophy that we need, abandoning void erudition and the ignes fatui of rhetoric. It is likely that Bobbio intended to promote such a reading of Hobbes who was then rather ignored and deeply misunderstood in Italy. This reading would, in fact, promote liberation from the rhetoric 
and provincialism that had characterized Italy and that the recently defeated fascists had turned into its distinguishing feature up to the point where Italy fell into social and moral debacle. In order to rebuild the country and consolidate a stronger and more mature form of democracy, especially in those years, Bobbio considered it necessary to get rid off the idealistic tradition and the void philosophy of Giovanni Gentile, so as to pave the way for social sciences and a positive, yet critical, philosophy.

This does not mean that Bobbio candidly believed Hobbes to be tout court the philosophical flag-bearer of democracy. Rather, he considered Hobbes to be the political thinker that had produced the most solid argumentation for the theoretical foundation of the modern state; the legitimacy of which is based on consensus, making democracy its most consistent form of government, even though it had been rejected by Hobbes. For this reason in particular, Bobbio was well aware of the fact that Hobbes, on more than one occasion, seemed to be a two-faced Janus. On one hand, he wanted to erect his civil philosophy on the grounds of rational argumentation, in the place of dogmas. On the other hand, he dogmatically withheld that such a civil philosophy could only be one - his own - just like geometry could only be Euclid's. On one hand, he rejected the principle of authority, and on the other hand, he ascribed the strictest control over ideological power to the Sovereign, thus making the practical sphere a dimension subjected to sovereign authority and not the place for the unobstructed quest for truth. (In effect, private judgment on good and evil is the source of seditious doctrines and therefore the cause of the very failure of the State). Perhaps, we could say that Hobbes erected part of the conceptual architecture of modern democracy but at the same time he strangled it by refusing to give it the air it needs: Plurality of opinions and interests. Perhaps, he did so out of fear of the fragmentation and confusion among powers that was typical of the medieval political universe. 
If Hobbes' methodological contribution had consisted generically in the definition of reason as a faculty of computation, and hence in founding political science upon this calculus, it would have been not only modest, but also ambiguous. Bobbio unravelled the ambiguity and (over)generalization by critically sorting out the cornerstones of Hobbes' conceptual framework without linking it to Hobbes' obsessive fear of political, economic, social and ideological conflict that necessarily leads to civil war, and that made him opt for the monocratic sovereign. In Bobbio's reading, Hobbes is (foremost, not barely) the founding father of modern contract theory; a model that he defined as "Hobbesian" in opposition to the Aristotelian model. This model of modern natural law —or "Hobbesian model" if you prefer - that starts with the state of nature and becomes a civil society trough the social covenant is grounded in an individualistic worldview. In all its different versions or variants, this model holds the individuals (not families, groups or communities) to be the foundational elements of the political universe that cannot be further divided.

It might be objected that this is an issue of substance and not of method. Bobbio claimed he had "substantial" and not only methodological dues in respect of Hobbes, as far as the preference for individualism and theoretical thrust toward contract theory are concerned. This is true for individualism, and less for the construction of the Hobbesian model. Again, it might be suggested that if we were to name an adjective for qualifying individualism that has been used to the point where an overlapping consensus was almost reached between truly alternative conceptions, this adjective would have to be "methodological". As we shall see next, Bobbio was right in considering this "minimal" way of conceiving individualism to be useless: As methodological individualism tried to save at least the core of individualism from controversy, it only drained it of meaning. 
But let us go back to what I hold to be Bobbio's deepest methodological debt toward Hobbes: Demonstratio supervening interpretatio, the principle of reason overcoming the principle of authority. In other words, the geometric or mathematical-like reasoning applied to politics. The stern chain of deductions fascinated Bobbio. Nevertheless, he saw that the logical proceeding hid ontological preferences, conventional definitions and preconceived ideas; notions that do not become self-evident even though they are sustained by significant empirical data. To me, it seems that the methodological aspect that Bobbio appreciated the most in Hobbes, and that he accredited him with more than any other author, was the emphasis laid on the following fact: For its heuristic aims and for the comprehension of "social reason" operating in politics and in its keywords, the dichotomist and dilemma-based reasoning is the most adequate in political theory, if not its sole form of reasoning. The spheres of praxis and history are the reign of compromise, mediation, nuance, where many cases need to be taken into consideration. This circumstance has to be accounted for in theory, in order to avoid generating monsters by excess of reason and by confusing theory with practice. Nevertheless, insofar as theories attempt to shed light on practical, historical events, by criticizing or justifying them, they have to be radical, extreme, or if you prefer, extremist. Theory has to free itself from the suffocating clutch of contingency if it shall be able to single out and to point to the thresholds and bifurcations of political practice and history by and large.

The dichotomist model that, according to Bobbio, should be labelled "Hobbesian", or in other words the great dichotomy that rule over the universe of modern politics, is based on certain elements. Through these constitutive elements, Hobbes offers the most consistent justification of political obligation. Chiefly, he does this on the basis of the "influential metaphysics" of individualism that replaced the holistic and organic worldview. In Bobbio's work on Hobbes, he 
continuously stressed Hobbes' fruitful extremism or theoretical radicalism. This extremism results from Hobbes' dichotomist proceeding. However, the importance of Hobbes' lesson emerges even more clearly when Bobbio does not deal with Hobbes, but with the great (and lesser) dichotomies themselves. This line of reasoning is the only method that we have for arranging the practical world and to find our way within it, in descriptive, prescriptive and historical terms.

Bobbio declared: "All human history, imaginative and not, of our role in society is characterized by the building of "great dichotomies" starting from the one between the state of innocence and the state of corruption" (Bobbio 1977: 135). This is not only true for the two centuries of contract theory but for "all human history". It should not come as a surprise that the essay from which I excerpt the quote is dedicated to the dichotomist structure of the thought of Friedrich von Hayek. Here, Bobbio referred to the fact that proceeding through dilemmas and dichotomies is the only method that enables the correct functioning of practical reason, or perhaps even of thought itself. Indeed, to Bobbio, even the tricotomist structure is a variation of an essentially binary or dichotomist scheme, with a duplication of one of its elements, as a returning moment. Without forgetting the great philosophers who used a threefold structure - such as Vico, Comte and, of course, Hegel- Bobbio observed that, beneath many apparent threefold structures, we find dichotomies that are less rudimentary, or more sophisticated. This can be noticed principally in philosophy of history. Bobbio did not only have in mind the variations on the Hobbesian model that were introduced by contract theorists like John Locke and Jean Jacques Rousseau. He also bore in mind the proponents of a dialectical interpretation of history, of which Marxism is a typical case: "At least on its prophetic side, [Marxism belongs] to the history of great dichotomies (the realm of necessity/the realm of liberty, prehistory/history, class society/the classless society)". If 
this is true for Marx and Engels, then we might ask whether the tripartite thought is nothing but a dichotomy-based thinking articulated in triads instead of dyads; in other words, "the triadic use of a dichotomy (...) connected to the dialectical interpretation of the course of history". Even though Bobbio found the very model of authentic trichotomist thinking in Hegel, his Hegelian studies -starting with Diritto privato e diritto pubblico in Hegel- are good examples of attempts to enucleate what is really important in Hegel's political thought on the basis of dichotomies.

It can be objected that thinking on the basis of dichotomies was not Hobbes' invention. It suffices to mention that, according to Bobbio, the opposition between the private and the public sphere, which is the great dichotomy par excellence goes back much further than Hobbes, and more precisely to the foundations of Roman Law in the Corpus iuris civilis. Nonetheless, for Bobbio, it was Hobbes' merit to have turned dichotomist reasoning into the sharpest sword of rational argumentation in practical matters and to have left this heuristic and explanatory weapon in legacy. This instrument does perhaps not resolve all tensions and contradictions, but it clears quite a few of them, by elucidating their nature and ratio essendi.

Before moving on to discuss Hobbes' second great lesson -individualism - another objection needs to be addressed: Roland Pennock's "Hobbes's confusing 'clarity'. The case of "liberty" inevitably slips to mind to the frequent and assiduous reader of literature on the philosopher of Malmesbury. Pennock's essay ends with the following statement: "It would appear, in any case, that there was either madness in his method or method in his madness, or both" (Pennock 1965, 116). Pennock vigorously challenged the appearance of clarity and demonstrative strength of Hobbes' reasoning, not only as far as the notion of liberty is concerned but in general terms. According to Pennock, Hobbes' reasoning is a way of arguing that, beneath the surface, is blurred and 
confusing. It is an inconclusive set of definitions and demonstrations generated by a perverse use of logic. Pennock pushed this line of arguing even further: "Hobbes's political philosophy contains too many confusions ad inconsistencies to be covered by any single explanation. Probably the nearest approach to such a single explanation, however, runs in terms of his methodology, his addiction to all-ornothing arguments, his unwillingness to qualify or to deal in matter of degree" (Pennock 1965, 115-116). The target is precisely the dichotomy- and dilemma-based way of thinking that Bobbio admired in Hobbes. I do not intend to reject Pennock's reasoning in detail, even thought it always seemed, to me, to be more of an ad hoc ploy than any well-founded argumentation. However, it is hard not to ask whether this criticism cannot be applied to Bobbio as well; and if he has ever been charged, perhaps in less direct terms, of reducing political thought overall to great and derivate dichotomies by the use of such devices. It might seem that this is the case if we look at the way Bobbio defended the analytical and dichotomist method against various forms of historicism born out of, broadly speaking, the matrix of idealism and Marxism. He felt the need to defend this method just as he introduced the Hobbesian method as the "modern" alternative to the time-honoured Aristotelian model.

At any rate: Was Bobbio liable of confusing clarity? Did he fail to see the matters of degree? I do not believe so. What he meant to do is to distinguish properly (in a way that is not devoid of a Hobbesian touch) pure theoretical models (that present themselves as eminently descriptive or prescriptive, or as a philosophy of history) and the complex historical chains of events, without ever separating them completely, as analytical philosophy often does. His intention was to distinguish between the models and the ineluctably ambiguous course of events, with its compromises and institutions, always flawed compared to the model. Hobbes had already answered, almost annoyed, to those 
who wondered where the state of nature had taken place, that it was a hypothesis of reason. It did certainly not lack partial epiphanies in history, in various nuances and to different degrees, but its aim was to build a flawless theory of political obligation and not to reconstruct the historical processes of how the existing states came to be. The great dichotomies, the secondary dichotomies, and the whole art of distinguishing that prioritize aut aut and tertium non datur, represent possible theoretical ways of understanding reality. Since reality is in itself ambiguous and multi-facetted, it only shows more or less monstrous form of hybrids and mixes. For example, we know all too well that pure democracies or pure autocracies cannot be found in practice, but only combinations that tend towards this or that end of the segment, the extremes of which are made out of pure forms of democracy and autocracy. It is a matter of degree, a question of major or minor distance from one of the extremes. However, in order to grasp what democracy and autocracy are, first we need to reason in dilemmatic terms. Then we might establish a criterion for the intermediary point where a specific, historically given constitution is posited. In this case, the dilemma is constituted by bottom-up or top-down distribution of power.

What should not be confused is theory and ideology; a far too recurrent slip in those who, more or less openly, criticized Bobbio of reducing political theory to oversimplified and misleading models. Ideology, not theory, twists historical reality in deceptive and tragic ways in order to fit manicheist explanations and simple and absolute solutions. This is specifically the point Bobbio makes in a newspaper article - an unexpected occasion-:

All human history is a continuous motion of thrusts and setbacks. History is shaped in such a way that it seems to object to those who believe history follows the logic of contradictions and excluded middle; a view dear to the ideologists of "socialism or barbarism" or, vice versa, "capitalism or gulag". On the contrary, the principle of history seems to be 
FORMS AND LEVELS OF RATIONALITY IN HOBBES

the principle of the "included middle". It can be understood as one better prefers as a synthesis of opposites, albeit via approximate and unsatisfying formulas, where the "third" includes the other two elements. History can be understood as the "middle" in-between two extremes that are hence excluded; as a compromise, roughly speaking, where the "third" has feats of both the one and the other. [Bobbio 1981, 60]

Unsurprisingly, the example that Bobbio gave was the century-long strife between king and parliament. Following Hobbes' logic, the stake was that the sovereign power, in order to be truly sovereign, could not be divided. However -Bobbio observed - "the outcome was the synthesis -or, in less noble terms, a mix up; vulgarly speaking, a compromise- of constitutional monarchy that lasted and filled a historical function that no one challenges" (Bobbio 1981: 60). The point is nonetheless that the compromise of constitutional monarchy cannot be fully understood if Hobbes' argument against the indivisibility of sovereign power is not taken seriously into account. His argument is, in Bobbio's phrasing, based on "a dilemmatic reasoning typical in Hobbes". The suspicion of confusing clarity does not involve Hobbes and Bobbio as much as those historians and philosophers that are neither able to shed light on history through the lens of theory, nor to supply theory with facts of history by paying attention to its tough rejoinders.

\section{INDIVIDUALISM(S)}

The second great debt for which Bobbio gives credit to Hobbes seems prima facie superficial and generic. Certainly, Hobbes proposed an individualistic founding and an artificial view of politics, in net opposition to the holistic and organic world view of ancient times. To Bobbio, the atom of political society is the individual, not the cell represented by the family (or, as Aristotle claimed, the bare minimum of the union between a man and a woman). However, it might 
be objected that beneath the surface of this largely shared "influential metaphysics" the individualistic worldview that, according to Bobbio, is the basis of modern democracy is muddled and entangled with the primacy of rights on duties and foremost with the four great liberties of modernity: personal liberty, freedom of speech, freedom to assemble and freedom of association. These are the indispensable premises for making political rights and universal suffrage meaningful as means by which we express -in a responsible albeit indirect way- our preferences between alternative political programs, and not simply elect a chief or leader, leaving the collective decision-making up to him. This means that, in the end, public power rests upon the individual; an idea strictly opposed to the almost boundless "grammar of obedience" that Hobbes invented. The divergence is enormous between the residual freedom of Hobbes' subject-citizens and the subjective rights granted by the Rechtsstaat that Bobbio always defended. The difference is immense between the de facto limits, the "deontological codex" that Hobbes suggested that the Sovereign has to respect out of political prudence, and the legal bounds imposed on the Sovereign by the constitution.

While developing the core of the Hobbesian model, Bobbio indisputably acknowledged that individualism is the foundation of modern democracy, since it is the premise in order to assert the artificial and conventional nature of the State and hence its foundation in consensus. This latter grounding is strengthened in democratic rule of law, which is the most evolved form of the modern territorial state. In my view, these aspects, no matter how undisputable they are, should not be the only ones mentioned when it comes to the influence of Hobbes' individualism on the political thinking of Bobbio. I speak of Hobbes' individualism, and not of the generic individualism of modern natural law theories, such as that of Rousseau, Locke and Kant. This influence has two directions, distinct and yet correlated: On one hand, it is present in the refusal of Locke's "owner-fo- 
FORMS AND LEVELS OF RATIONALITY IN HOBBES

cused individualism" appropriated by much of the subsequent liberal tradition; on the other hand, Hobbes' influence can be felt in the dissatisfaction and unrest that Bobbio feels for the so-called "methodological individualism" which has dominated economics and social sciences for the last two centuries.

As far as the first direction is concerned (the refusal of Locke's "owner-focused individualism"), it suffices to mention the criticism Bobbio made, by opposing it to democratic individualism:

All individualisms are not alike. There is the individualism of the liberal or libertarian tradition, and there is the individualism of the democratic tradition. The first form of individualism cuts the string between the individual and the organic society and sets him outside the motherly womb, in a unknown world, full of dangers from the struggle for life, where all have to look after themselves, in a perpetual fight, exemplified by Hobbes bellum omnium contra omnes. The second form of individualism unites him with others; individuals similar to himself, that he considers his peers, so as to recompose society through their union; no longer as the organic whole from which he left, but as an association of free men. The first form of individualism calls for the individual's freedom from society. The second form calls for a reconciliation between the individual and society, turning the latter into a free agreement among free and intelligent human beings. The first form turns the individual into the absolute protagonist, clear of every social tie; the second makes him the leading figure in a new society that arises from the ashes of the old, and where collective decisions are taken by the very individuals or by their representatives (Bobbio 1999: 334).

In this passage, Bobbio does not only take on the Hobbesian terms and modalities: The reasoning is clearly dilemma-based. Moreover, substantial elements of Hobbes' thought can be found here, implicitly as well as explicitly. Here I shall only point to two such substantial elements, strictly interconnected. 
a) The libertarian or owner-focused individualism is necessarily an advocate of the "Night Watchman State" (or "minimal State"). Such a state would lack almost all characteristics of Sovereignty according to Hobbes. To Bobbio, it would not emancipate the individual from the struggle for life which characterises the state of nature. Such a state is only a less crude and miserable version of the bellum omnium contra omnes, the abolition of which was the objective of Hobbes' political artifice.

b) The refusal to believe that ownership and endless accumulation of wealth is in the nature of things, as if it represented the very sense of a man's life, giving rise to the impression that protecting property is the state's main, if not only, ratio.

Hobbes vigorously contested ante litteram this libertarian point of view by conferring to the Sovereign a public, collective and political dimension and the authority to attribute, retrieve, and distribute ownership and material possession of goods among individuals (now citizens). Bobbio contested the libertarian point of view without contesting the liberalism of rights. This latter takes the form of "reconciliation" between the individual and society, a feature typical of democratic individualism where, in other words, politics is prioritized over economics, just as law enjoys priority over economics in the "reunion" of individuals within society, another feature Bobbio typically ascribed to democratic individualism. To Bobbio, this priority is linked to the idea that fundamental rights of individuals - whose "union" (yet another of Hobbes' terms) create society- are quite different from particularistic ownership rights: They form the network of what Habermas defined as "solidarity among strangers". This is the network thanks to which democracies (ought to) limit the perverse effects of the market and its savage powers. Such market failures indirectly stem from the ideology that turns the individual into the "absolutely free protagonist" who acts as if he were clear of all social ties. Such an ideology has forgotten the lesson of 
FORMS AND LEVELS OF RATIONALITY IN HOBBES

Hobbes on the natural equality of fragile and mortal individuals, according to which no one, no matter how strong or gifted he might seem, is safe enough to be sure his "neighbour" will not overcome him.

As far as methodological individualism is considered, Bobbio wrote:

At the origin of individualism we find a form of ontology and a form of ethics: An ontology because it hinges on an atomistic conception of society and of nature by contrast to the prevailingly organic conception; a form of ethics because man has a moral value, differently from all other beings existing in the natural world; or in Kant's terms, man has dignity, not just a price. Today, individualism has become a method ("methodological individualism" advocated by sociologists and economists in recent years). In other words, it has become the expression of preference, with all the following consequences for the study of social phenomena starting from the actions of the single individual instead of starting from various forms of society (Bobbio 1999: 345).

Elsewhere he stated:

The individualistic conception has endorsed the most worn out version of methodological individualism (...). The two most complex sociological systems of our century, Pareto's and Weber's, are individualistic in this meaning (...). Lest undue absolutisation of any method, it is important to keep in mind that methodological individualism was born within the field of economics and it has its operating force within it (purposefully Pareto and Weber were economical sociologists). This method should not be transposed into other fields where collective phenomena cannot be explained on the basis of individual choice - as in the case of language and, to certain extent, law-; therefore, these fields of study have always, just as erroneously, upheld and legitimated an absolutification in the opposite direction, towards organicism (Bobbio 1999: 333-334). 
When reading these quotes, it might seem wrong and paradoxical to see a Hobbesian influence in the way Bobbio addressed the question of the form of individualism. To be sure, the reference is close at hand: e.g., Bobbio held atomistic philosophy of nature and nominalism in logic to be the ontological origin of individualism. But he was well aware of the fact that this philosophy of nature, as well as logical nominalism is philosophically and scientifically out of date. The up-to-date distinction is between ethical and methodological individualism. Hobbes is implicitly present in Bobbio's reasoning in that he is set in contrast to Kant. Kant believed us to have primarily dignity, not a price, whereas Hobbes, so to say, set the price of a man in terms of his value on the market square. Prima facie, Bobbio seems to tend towards Kant's ethical individualism.

Furthermore, Hobbes - as we have already stressed- is often held to be the father of game theory and, more generally speaking, of rational choice theories and thus of the more recent and accredited versions of "methodological individualism". Bobbio clearly warned us about these theories being applied "universally", indiscriminately, resulting in a narrow economic view of the world and our place in it.

Since a method and theory that allegedly explain everything with categories taken from one single field have an ideological touch (let alone an intention to tout), methodological individualism is not at all neutral: Under the cloak of the rational actor, we find a common sense utilitarism, a theory of preference reduced to the field of economics that cannot be directly associated with Hobbes' claim that "Profit is the measure of Right" (De Cive, I, 10).

From this synthetic and efficient formula we can evince that Hobbes was not a forerunner of preference utilitarism and, generally speaking, of the worldview focused on the model of the market economy that was developing in his lifetime. "In a State of Nature" means in the state that people have to strive to abandon by means of a far-seeing calculus, the premise of the "covenant", and of the entry into 
"civil society". Hereby we go back to Bobbio's conception of individualism that does not cut off the ties between the individual and society, but instead broadens and strengthens these attachments through political responsibility and the mediation of law.

Another legacy of Hobbes deserves attention. As I have mentioned, Bobbio seemed to have preferred Kantian ethical individualism, both for its own sake and as a basis for modern democracy. He was, however, aware that Kantian innatism risks introducing once more the disruptive element of the classical doctrine of natural law; thus jeopardizing the artificiality of law, legal positivism and, with it, the whole construction of the modern state that poses the norms of civil society rather than recognizing them as ultimately divine or natural. With Kant, the risk is to endorse, in some new form, traditional ontology. Such ontology presupposes the existence of an order of the world, objectively corresponding to the categories used by men to confer order to it.

To Hobbes, the only order that we can understand is the one we have manufactured artificially. To Hobbes, even mechanical materialism is only an hypothesis of order in the world, albeit the most likely. Politics and law are purely artificial orders. Still, this does not mean that the individualism that survives in Hobbes is only the methodological aspect, i.e. the idea of taking the state to pieces, to elementary units in order to understand its functioning, according to his famous metaphor of the clock. When we recompose the clock, there is something more to it. In Hobbes, great weight is put on those prudential prescriptions that he traditionally continues to call natural laws; and the weight depends on the fact that this is the setting in which the terms of the agreement are established so to make the covenant acceptable to all. Under these conditions, in this sort of preceding settlement, what cannot be given up is the recognition of the equality of the future contracting parties. If it shall not fail, the covenant must bring together people who 
are morally, politically and economically similar: Nobody can set a clause pursuant to which further benefits can be claimed in the future. Alleging to have suffered prior renunciation of greater kind is no argument. These are the assumptions of Bobbio's democratic individualism. Overall, these assumptions are closer to the realistic recognition of equality that stems from Hobbes, than they are to Kant's Sollen.

\section{The Rational Bond. Laws of Winning and Laws of Gaming}

In the reflections on the modern state begun by Hobbes, the thread of Ariadne is stressing the fact that the decision of the sovereign has to be subjected to rationality. Not only are irrational decisions logically ruled out owing to the motives (peace and security) and the way (consensus) the state is instituted. But common sense also tells us the Sovereign shares the interests of his subjects. Hobbes claimed that the force of a Sovereign lies in the material and moral wealth of his subjects. To Hobbes, it is an absurdity to grind the subjects down with useless and cumbersome regulations, or anyhow induce discontent or perhaps even rebellion:

For the use of laws (which are but rules authorized) is not to bind the people from all voluntary actions, but to direct and keep them in such a motion as not to hurt themselves by their own impetuous desires, rashness (...); as hedges are set, not to stop travellers, but to keep them in the way. And therefore a law that is not needful, having not the true end of a law, is not good. A law may be conceived to be good when it is for the benefit of the sovereign, though it be not necessary for the people, but it is not so. For the good of the sovereign and people cannot be separated. It is a weak sovereign that has weak subjects; and a weak people whose sovereign wanteth power to rule them at his will (Leviathan, $\mathrm{XXX)}$. 
FORMS AND LEVELS OF RATIONALITY IN HOBBES

Therefore, even if the covenant confers upon the Sovereign (man or assembly) the faculty of acting even so arbitrarily, the implicit assumption of this whole reasoning is that a power is instituted that is able to subject all only to create a society that takes on, and guarantees through law, what straight reasoning suggests to all men in those rare moments when our passions are silenced: "But by safety must be understood, not the sole preservation of life in what condition soever, but in order to its happiness. For to this end did men freely assemble themselves, and institute a government, that they might, as much as their humane condition would afford, live delightfully" (De Cive, XIII, 4).

In the dawning of the modern state, the ideology of common interests between Sovereign and subjects could still be upheld, because of the relatively simple network of social and economic relationships that it referred to. These relationships - labelled the "systems subjected political and private" in the $22^{\text {nd }}$ chapter of Leviathan - became known as "civil society" from Ferguson onwards. The transformations of the modern territorial state, along with an increasingly complex civil society, have made the plurality of contrasting interests quite clear. Consequently, the constraints of rationality have turned into a requirement of an evermore detailed constitutional limitation of sovereign power. We might say that, for Bobbio - as for all those who recognize themselves in the legacy of modern contract theory and Enlightenment - what Hobbes believed to be merely rules of political prudence - rules for gaining and maintaining power - have to be transformed into "laws of gaming", the rules of the game, that assess the rationality of political power, not only as an internal and purely prudential game, but rather as an external and cogent constraint. On a higher and more distinct level of rationality, this limitation has to be turned into fundamental rights following the wit of the written constitution that characterizes democratic rule of law (this has already occurred to a certain extent). Did Hobbes not suggest, en passant, the metaphor of "laws 
of gaming" in Leviathan? To be sure, he did not distinguish constitutional principles from norms and statute laws, yet he perceptively stressed that "it is in the laws of a Commonwealth, as in the laws of gaming: whatsoever the gamesters all agree on is injustice to none of them" (Leviathan, XXX).

The advocates of political realism that mock constitutionalism and fundamental rights ought to ponder upon the fact that, with a minimum of common sense and historical awareness, it is possible to consider Thomas Hobbes as one of the key authors of constitutionalism, set at the very beginning of the long history of rule of law.

\section{REFERENCES}

BobBio, N., Dalla struttura alla funzione. Nuovi studi di teoria del diritto, Milano, Comunità, 1977.

- Le ideologie e il potere in crisi, Furenze, Le Monnier, 1981, p. 60 [Originally published on "Avanti!", 11-03-1978 with the title Una società mai vista?].

—, Thomas Hobbes, Torino, Einaudi, 1989 [Eng. trans. by Daniela Gobetti, Thomas Hobbes and the Natural Law Tradition, Chicago-London, University of Chicago Press, 1993].

- Le riflessioni di un ottuagenario in N. Bobbio, De senectute e altri scritti autobiografici, Torino, Einaudi, 1996.

_-, Teoria generale della politica, M. Bovero (ed.), Torino, Einaudi, 1999.

Gauthier, D. P., The Logic of Leviathan, Oxford, Clarendon Press, 1969.

HAMPTON, J., Hobbes and the Social Contract Tradition, Cambridge, Cambridge University Press, 1986.

KAVKA, G., Hobbesian Moral and Political Theory, Princeton, Princeton University Press, 1986.

MAGRI, T. Saggio su Hobbes, Milano, Il saggiatore, 1982 
FORMS AND LEVELS OF RATIONALITY IN HOBBES

Pennock, J. R., "Hobbes's Confusing 'Clarity", in K. C. Brown (ed.), Hobbes Studies, Oxford, Blackwell, 1965.

REAlE, M., La difficile eguaglianza, Roma, Editori Riuniti, 1991.

SCHMITT, C., Der Leviathan in der Staatlehre des Thomas Hobbes, Hamburg, Hanseatische Verlaganstalt, 1938 [The Leviathan in the State Theory of Thomas Hobbes. Meaning and Failure of a Political Symbol, Translated by George Schwab and Erna Hilfstein, Chicago-London, University of Chicago Press, 1996].

Strauss, L., The political Philosophy of Hobbes. Its Basis and its Genesis, Oxford, Clarendon Press, 1936.

Vialatoux, J., La cité de Hobbes, théorie de l'état totalitaire, Paris, Lecoffre, 1935.

WARrender, H., The political Philosophy of Hobbes. His Theory of Obligation, Oxford, Clarendon Press, 1957.

WATkins, J. N. W., Hobbes's System of Ideas, London, Hutcheson, 1965.

ZARKA, C. Y., La décision métaphysique de Hobbes, Paris, Vrin, 1987. 
DR (C) 2012, Universidad Nacional Autónoma de México,

Instituto de Investigaciones Jurídicas 